\title{
Review: Strategi Praktis Penanganan Egg Drop Syndrome pada Unggas Petelur
}

\author{
A Review: Practical Strategy for Egg Drop Syndrome in Laying Hens
}

\author{
H. Khasanah ${ }^{1 *}$, D. G. Silaban ${ }^{1}$, A. Priyono ${ }^{1}$, A. Dinnar ${ }^{1}$, L. Nashrullah ${ }^{1}$, dan G. Syaikhullah ${ }^{2}$ \\ ${ }^{1}$ Program Studi Peternakan, Fakultas Pertanian, Universitas Jember \\ Jl. Diponegoro, Bondowoso, Jawa Timur 68251 \\ ${ }^{2}$ Jurusan Manajemen Agribisnis Unggas, Politeknik Negeri Jember. Lingkungan Panji, Tegalgede, \\ Kec. Sumbersari, Kabupaten Jember, Jawa Timur 68124 \\ Corresponding Author : himma@unej.ac.id
}

\begin{abstract}
Layer poultry business is a prospective business due to meeting the need for animal protein from eggs. The average consumption of eggs is $2,152 \mathrm{~kg}$ per capita per week. These promising business prospects were not accompanied by an increase in the productivity of laying hens. Abnormal conditions such as cases of poultry disease will plunge the supply of eggs into a drop. One disease that is considerably popular in laying birds is Egg Drop Syndrome (EDS). This review aims to examine the EDS handling strategies in laying birds to prevent decreased egg production. Materials and methods through literature study. Some strategies that farmers can take to prevent EDS are vaccination, maintaining sanitation and cleanliness of pond land, including biosecurity, and using herbs as feed additives.
\end{abstract}

Key words: Laying hens, Egg Drop Syndrome, handling strategy, vaccine, phytobiotics

\begin{abstract}
ABSTRAK
Usaha unggas petelur merupakan usaha yang prospektif karena dapat memenuhi kebutuhan protein hewani dari telur. Rata-rata konsumsi telur adalah $2.152 \mathrm{~kg}$ per kapita per minggu. Prospek bisnis yang menjanjikan tersebut tidak dibarengi dengan peningkatan produktivitas ayam petelur. Kondisi tidak normal seperti kasus penyakit unggas akan menjerumuskan pasokan telur hingga turun. Salah satu penyakit yang cukup populer pada unggas petelur adalah egg drop syndrome (EDS). Kajian ini bertujuan untuk mengkaji strategi penanganan EDS pada unggas petelur untuk mencegah penurunan produksi telur. Metode penulisan melalui studi pustaka. Beberapa strategi yang dapat dilakukan peternak untuk mencegah EDS adalah vaksinasi, menjaga sanitasi dan kebersihan lahan tambak, termasuk biosekuriti, dan menggunakan tumbuhan sebagai aditif pakan.
\end{abstract}

Kata kunci: Ayam petelur, egg drop syndrome, strategi penanganan, vaksin, fitobiotik

\section{PENDAHULUAN}

$\begin{array}{cccc}\text { Usaha } & \text { unggas } & \text { petelur memiliki } \\ \text { ketertarikan } & \text { tersendiri } & \text { karena } & \text { mampu }\end{array}$
menghasilkan keuntungan yang layak dan menghasilkan produk yang dibutuhkan oleh manusia (Afandi et al., 2019). Namun, peternakan unggas petelur memiliki kendala yaitu maraknya berbagai penyakit infeksi yang bersifat kontagius, yang disebabkan oleh virus, bakteri, fungi dan riketsia (Brown Jordan et al., 2018; Gowthaman et al., 2019). Penyakit akibat virus pada unggas petelur utama disebabkan oleh famili Avian paramyxoviridae termasuk infeksi Egg Drop Syndrome Virus (EDSV) (Kencana et al., 2017). Penyakit Egg Drop Syndrome (EDS) ditemukan pertama kali oleh Van Eck di Belanda pada tahun 1976 sebagai penyebab menurunnya produksi telur. EDSV ini banyak ditemukan menyerang ternak unggas petelur seperti ayam, bebek, itik, angsa, burung onta (Changjing et al., 2016).
Ternak yang terinfeksi EDS'76 menunjukkan gejala dengan kondisi telur berkulit lunak serta tipis, kulit telur tidak berpigmen bahkan ditemukan kasus telur tidak berkerabang sama sekali (Suresh et al., 2013). EDSV mampu menurunkan produksi telur secara drastis yang menyebabkan kegagalan dalam pencapaian masa puncak produksi meskipun ternak terlihat sehat, selain itu, daya tetas telur juga mengalami penurunan (Begum et al., 2013).

Di Indonesia, dilaporkan bahwa seroprevalensi EDS ternak itik di Badung Provinsi Bali sebesar 32\% (Kencana et al., 2019). Insiden EDS juga dilaporkan di daerah Kupang, Medan, Surabaya, dan Bogor. Penyakit EDS ini sering kali keliru dengan infeksi Avian Influenza, Newcastle Disease, Infectious Bronchitis dan kondisi melting phase yang sama-sama menunjukkan penurunan produksi telur (Ditjennak, 2014). Terganggunya masa puncak produksi unggas petelur akibat 
EDSV dapat menimbulkan kerugian ekonomis yang besar bagi peternak (Brown Jordan et al., 2018). Oleh karena itu dalam artikel review ini disajikan strategi penanganan pra dan pasca Egg Drop Syndrome pada unggas petelur sebagai upaya pencegahan kasus serangan EDS terhadap penurunan produksi telur. Artikel ini merupakan hasil review dari penelitian dan literatur terkait EDS.

\section{HASIL DAN PEMBAHASAN}

\section{Etiologi dan Patologi EDSV}

Virus Egg Drop Syndrom (EDSV) termasuk dalam klasifikasi Adenovirus A family Adenoviridae. Virus ini juga dikenal sebagai duck adenovirus (DAdV-1) dan dilaporkan pertama kali pada tahun 1976 sehingga virus ini dikenal sebagai EDS-76 (Marek et al., 2014). Hasil studi molekuler menunjukkan bahwa virus ini memiliki perbedaan dengan adenovirus lain yang ditemukan pada bebek namun mirip dengan adenovirus yang ditemukan di kambing, sapi dan possum. Selanjutnya, virus ini dikategorikan dalam AT-Adenovirus yang merefleksikan tingginya basa AT dalam DNA. Berat molekulnya sebesar 22.6×106 d (Changjing et al., 2016). Morfologi virus EDS dapat dilihat pada Gambar 1. Virus EDSV beramplop dengan 6 capsomer dan proses reproduksi secara in vivo yang ditemukan pada sel epitel infundibulum kelenjar tubular shell, isthmus, mukosa nasal dan limfa unggas yang terinfeksi (Mansoor et al., 2011). EDSV rentan terhadap pemanasan suhu $60{ }^{\circ} \mathrm{C}$ selama 30 menit, namun mampu bertahan pada pemanasan $56{ }^{\circ} \mathrm{C}, \mathrm{pH}$ 3-10 dan resisten terhadap kloroform (Absalón et al., 2017)

Gejala klinis Egg Drop Syndrome biasanya terlihat pada ayam yang berumur 25-35 minggu dengan gejala umum berupa penurunan produksi telur disertai dengan kualitas yang buruk seperti hilangnya warna kulit telur, kulit telur yang lunak, tipis dan bahkan bisa tanpa kulit serta ukuran telur bisa menyusut hingga sangat kecil (Cha et al., 2013). Laporan dari Kencana et al. (2017) bahwa produksi telur dapat turun sebesar $20-50 \%$, hal ini berlangsung hingga 6 sampai 8 minggu, yang menyebabkan puncak produksi sulit untuk dicapai. Gejala lainnya yang nampak yaitu ayam terlihat sedikit lesu, nafsu makan menurun, jengger dan pial berwarna pucat dan kadang disertai diare ringan. Ayam yang terserang Egg Drop Syndrome sebelum mencapai dewasa kelamin sulit untuk mencapai produksi telur yang optimal (Kencana et al., 2017).
Penyakit ini dapat menular tidak hanya secara horizontal tetapi dapat melalui perantara peralatan, karyawan maupun ayam yang telah terinfeksi, penularan vertikal juga ditemukan pada kasus induk terinfeksi EDS sehingga menghasilkan telur yang membawa virus (Cha et al., 2013). Virus tersebut dapat mencemari kandang, tempat telur, maupun peralatan peternakan yang lain dan dapat menulari ayam yang sehat (Kencana et al., 2017). Sebelum ayam siap memproduksi telur (pada masa starter grower), virus EDS yang sudah menginfeksi ke dalam tubuh ayam seakan-akan tertidur. Saat ayam mulai memproduksi telur, virus ini mulai aktif serta berkembang biak dan kemudian penyakitnya menyebar ke ayam lain yang berada dalam satu kandang. Umumnya menyerang ayam petelur pada umur 25-26 minggu yang tidak divaksinasi (Hafez, 2011).

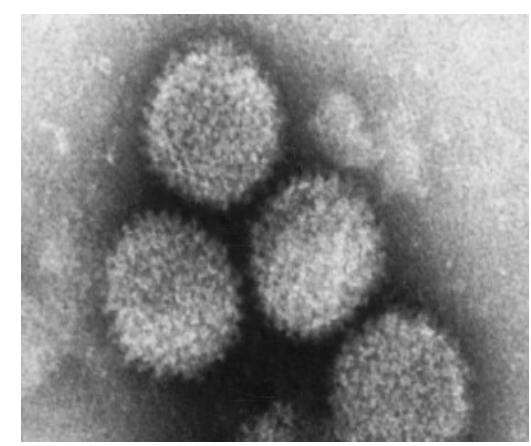

Gambar 1. Morfologi Virus EDS (Fitzgerald et al., 2019)

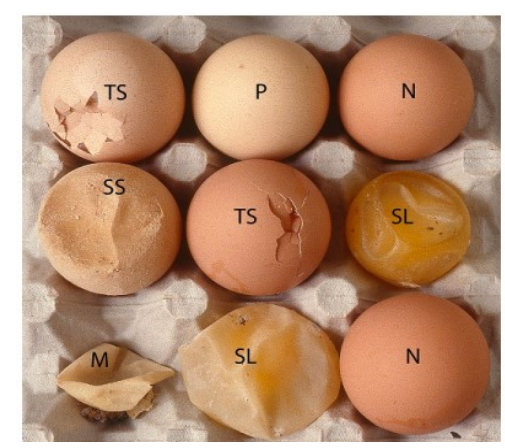

Gambar 2. Telur yang dihasilkan oleh ayam yang terinfeksi EDSV. TS= kerabang tipis; $\mathrm{P}=$ pucat, $\mathrm{SS}=$ kerabang telur halus; $\mathrm{SL}=$ telur dengan kerabang yang rusak (tidak sempurna); $\mathrm{M}=$ membran remnant kerabang; $\mathrm{N}=$ telur coklat normal (Fitzgerald et al., 2019). 
Penyebaran agen penyakit dapat terjadi dari satu peternakan ke peternakan lainnya. Penularan dapat berasal dari ayam yang sakit dan ayam sehat sebagai carier. Penularan dapat melalui bulu-bulu atau sayap, muntahan, kotoran, debu, peralatan dan sarana, peralatan perkandangan, lantai kandang, tempat telur, telurtelur dari flok-flok pembibit yang terinfeksi, bangkai yang dibuang sembarangan, kontaminasi air, serangga, rodensia maupun hewan liar serta burung-burung liar, bahkan penularan dapat terjadi melalui vaksin hidup atau kontaminasi vaksin yang tidak ditangani dengan baik, pakaian dari pegawai/operator kandang yang berpindahpindah kandang (Ezema et al., 2010; Suartha et al., 2010). Deteksi virus dapat dilakukan secara periodik dengan berbagai metode, adapun metode telah dikembangkan guna identifikasi EDSV disajikan pada Tabel 1.

Tabel 1. Metode deteksi EDS pada ternak

\begin{tabular}{|c|c|c|c|}
\hline No & Metode & Sampel Uji & Referensi \\
\hline 1 & $\begin{array}{l}\text { Haemagglutination test (HA) } \\
\text { dan Haemagglutination - } \\
\text { inhibition Test (uji HI) }\end{array}$ & $\begin{array}{l}\text { Sampel dari eritrosit, cairan } \\
\text { alantonis }\end{array}$ & $\begin{array}{l}\text { (McFerran et al., } \\
\text { 1977) }\end{array}$ \\
\hline 2 & $\begin{array}{l}\text { Antigen-capture enzyme-linked } \\
\text { immunosorbent assay (AC- } \\
\text { ELISA)-akurasi } 95 \%\end{array}$ & $\begin{array}{l}\text { F8 mAbs sebagai antibody } \\
\text { penangkap dan serum polyclonal } \\
\text { ayam terhadap virus EDS sebagai } \\
\text { antibodi pendeteksi }\end{array}$ & (Raj et al., 2003) \\
\hline 3 & $\begin{array}{l}\text { Polymerase Chain Reaction } \\
\text { (PCR) }\end{array}$ & $\begin{array}{l}\text { Gen L4 EDSV dari DNA virus } \\
\text { atau dari DNA jaringan ternak } \\
\text { yang terinfeksi. }\end{array}$ & $\begin{array}{l}\text { (Ockiya et al., 2020; } \\
\text { Begum, 2013) }\end{array}$ \\
\hline 4 & $\begin{array}{l}\text { duplex real-time fluorescence } \\
\text { RT-PCR assay }\end{array}$ & $\begin{array}{l}\text { Deteksi lebih cepat dan sensitive } \\
\text { dibanding PCR }\end{array}$ & (Zeng et al., 2015) \\
\hline 5 & $\begin{array}{l}\text { Real-time fluorescence loop- } \\
\text { mediated isothermal } \\
\text { amplification assay (RealAmp } \\
\text { Assay) }\end{array}$ & $\begin{array}{l}\text { Isolate virus dari cairan alantonis } \\
\text { tanpa ekstraksi DNA virus }\end{array}$ & (Zheney et al., 2018) \\
\hline
\end{tabular}

\section{Manajemen produksi unggas petelur}

Produksi dan kualitas suatu hasil ternak dapat dipengaruhi oleh berbagai macam faktor seperti iklim, pakan, sistem pemeliharaan, sistem kandang, dan kondisi geografis lingkungan tempat kandang ternak tersebut berada (Peña-Rueda et al., 2018; Henry et al., 2018). Laporan dari Setiawati et al., (2016) bahwa perbedaan suhu mengakibatkan gangguan produksi, kualitas interior dan eksterior. Suhu yang lebih rendah (18 ${ }^{\circ} \mathrm{C}$ ) memberikan pengaruh yang lebih baik pada hen day production, bobot telur, bobot telur dan konversi pakan dibanding ayam yang dipelihara pada kandang bersuhu tinggi $\left(30^{\circ} \mathrm{C}\right)($ Amijaya $e t$ al., 2018). Bentuk dan berat telur bergantung pada hereditas, umur induk, musim dan pakan (Saeed $e t$ al., 2017). Semakin tua umur induk semakin tipis pula kerabang yang dihasilkan karena penurunan kemampuan ayam dalam memenuhi kebutuhan kalsium (Park dan Sohn, 2018). Konsekuensi penyakit ini yakni produksi telur menurun dari sebanyak 40\% (Ezema et al., 2010). Tipe manajemen pemeliharaan juga mempengaruhi seroprevalensi kejadian EDS, ternak yang dipelihara secara intensif menunjukkan seroprevalensi yang lebih rendah $(20 \%$ positif EDS) dibanding ternak yang dipelihara secara ekstensif (75,56\% positif EDS) (Kencana et al., 2019). Faktor nutrisi penting dalam pengembangan organ awal dan kesehatan unggas petelur. Kekurangan nutrisi dan vitamin diawal pertumbuhan dapat menyebabkan gangguan perkembangan ovarium dan saluran telur yang tidak sempurna (Okolelova et al., 2017).

\section{Strategi pencegahan dan pengobatan}

\section{Pengembangan Vaksin EDSV}

Vaksinasi merupakan salah satu upaya pencegahan terhadap serangan virus, menurut sifat hidup agen infeksi, vaksin digolongkan menjadi dua yaitu: golongan pertama adalah vaksin aktif mengandung virus yang telah dilemahkan dan berfungsi sebagai stimulus pembentukan kekebalan bersifat lokal di permukaan mukosa dengan lebih cepat, vaksin ini meliputi active vaccine, live vaccine (Poudel et al., 2020). 
Golongan lainnya adalah vaksin inaktif merupakan vaksin yang didalamnya merupakan agen infeksi yang telah dimatikan tetapi masih mampu menstimulasi pembentukan antibody, golongan vaksin ini termasuk killed vaccine dan inactivated vaccine (Dharmayanti et al., 2014) .

Kencana et al. (2017) menjelaskan bahwa vaksin kombinasi inaktif ND-IB-EDS menunjukkan ayam petelur titer antibodi EDS yang tidak protektif, hanya protektif terhadap ND. Penelitian lain dari Kencana et al., (2018) menjelaskan bahwa kandidat vaksin untuk EDSV di Indonesia berasal dari isolate di Medan. Pengembangan vaksin tersebut terbukti aman pada uji klinis sebagai kandidat vaksin EDSV asli Indonesia dan mampu menstimulasi pembentukan antibodi 2 minggu setelah vaksin dengan titer antibodi $2^{5} \mathrm{HI}$ units dan $2^{7.3} \mathrm{HI}$ units untuk 3 minggu pasca vaksinasi. Upaya protektif dapat dilakukan dengan vaksinasi ulangan (booster) supaya sel memori dapat mempercepat respons antibodi (Vogel \& Manicassamy, 2020; Liu et al., 2020). Laporan dari Song et al. (2019) menjelaskan bahwa potensi vaksin subunit yang berbasis protein serat terpotong (truncated fiber protein) sebagai dosis tunggal efektif memproteksi ternak melawan EDSV. Vaksin isolat yang menggunakan adjuvant berbasis minyak dan aluminium hydroxid menunjukkan pengaruh yang nyata dalam melawan EDSV dan dilaporkan tidak ada penurunan produksi pada ayam (Ilyas et al., 2004.). Namun, perlu diperhatikan bahwa penggunaan vaksin yang berlebihan atau secara ekstensif dapat menyebabkan terjadinya mutasi genetik dan virus bersifat patogenik (Ashraf dan Shah, 2014).

\section{Biosekuriti, Sanitasi dan Hygiene Area Perkandangan Unggas Petelur}

Biosekuriti merupakan semua tindakan yang bertujuan sebagai pertahanan pertama dalam pengendalian wabah dan mencegah semua kemungkinan penularan atau kontak dengan ternak tertular dengan tujuan meminimalisir penyebaran agen infeksi. Menurut (Samanta et al., 2018) biosekuriti yang diterapkan pada peternakan terbagi menjadi tiga wilayah meliputi zona merah yakni zona kotor, batas antara lingkungan luar yang kotor contohnya tempat penerimaan tamu seperti pembeli ayam, technical service dan pengunjung, area ini sangat berpotensi terjadi cemaran penyakit. Sementara zona kuning ialah transisi dari zona merah ke zona hijau, area ini terbatas untuk truk, ransum, DOC, telur, area ini hanya diizinkan bagi pekerja kandang, sedangkan zona hijau ialah zona bersih yang di dalamnya terdapat unggas. Pada area ini harus menerapkan standar operasional prosedur sanitasi (Meirhaeghe et al., 2019; Gblossi et al., 2020). Menurut Trijaya, (2017) terdapat tiga elemen biosekuriti, meliputi isolasi atau pemisahan kandang, kontrol lalu lintas dan sanitasi. Hal ini sejalan dengan Grimes dan Jackson (2015) bahwa penerapan biosekuriti pada industri unggas petelur meliputi:

- Adanya kontrol pergerakan ternak unggas, manusia, peralatan, alat transportasi baik kendaraan antara dan ke dalam area peternakan

- Melakukan pemisahan ternak dari spesies unggas lain dan spesies burung non-unggas termasuk burung liar, hewan pengerat dan hewan lainnya serta serangga yang dapat menurlarkan penyakit.

- Minimalisir penyebaran secara aerosol melalui isolasi geografis

- Vaksinasi guna meningkatkan dan mengoptimalkan imun ungags

- Melakukan praktek kebersihan dan mengimplementasikan prosedur disinfeksi yang benar untuk menurunkan tingkat infeksi

- Memberikan pengobatan yang tepat

- Penerapan HACCP (Hazard Analysis Critical Control Point) dan identifikasi CCP (critical control point)

\section{Suplementasi Fitobiotik sebagai Peningkat Imun Unggas Petelur}

Menurut Haniarti et al. (2019) ramuan jamu sebagai feed aditif dapat diberikan dalam bentuk larutan melalui air minum dan bentuk tepung yang dicampur pada ransum. Jamu ternak memiliki keunggulan seperti harganya lebih murah, khasiatnya dirasa lebih efektif untuk pengobatan penyakit ternak unggas. Jauh sebelum terjadinya wabah flu burung, peternak unggas skala kecil telah menggunakan ramuan obat tradisional baik dalam bentuk air minum maupun dikombinasikan dalam ransum. Jamu ternak yang berasal dari perpaduan dari tanaman obat mengandung zat aktif yang bermanfaat sebagai antiviral, anti bakteri dan antibiotic (Vinus et al., 2018). Beberapa tanaman herbal yang berpotensi sebagai antivirus seperti sambiloto (Andrographis paniculate) dosis $0.4 \%$ dilaporkan memiliki pengaruh positif terhadap persentase produksi telur, konsumsi dan konsversi pakan bebek petelur (Yulianti dan Muharlien, 2020). 
Selanjutnya, (Krauze et al., 2021) melaporkan penggunaan minyak cinnamon dan asam sitrat dapat meningkatkan imun ayam. Tanaman tyme (Thymus vulgaris), minyak bergamot (Citrus bergamia)), cengkeh (Syzygium aromaticum), pepper (Piper nigrum) dapat meningkatkan produksi telur, kualitas telur dan imun ternak. Minyak esensial juga mampu berperan sebagai antivirus seperti minyak esensial dari kayu manis, adas manis, zaitun dan oregano (Widodo, 2020). Suplementasi $1 \%$ kunyit dapat meningkatkan hen day production dan bobot telur tanpa memberikan efek negative pada saluran pencernaan ayam petelur (Ooi et al., 2018). Pemberian daun binahong (Anredera cordifolia Ten.) juga dilaporkan mampu memperbaiki kesehatan saluran pencernaan dan digunakan sebagai imunomodulator (Widodo dan Khasanah, 2021). Penggunaan herbal ini dapat diaplikasikan secara tunggal ataupun kombinasi (Liu et al., 2009).

\section{KESIMPULAN}

Prospek usaha unggas petelur memang tidak akan pernah punah. Namun hal ini akan menjadi sia-sia jika tidak diiringi dengan upaya peningkatan produktivitas ayam petelur yang berkelanjutan. Penyakit Egg drop syndrome perlu diperhatikan karena dapat menurunkan produksi telur dan kualitas telur dan merugikan secara ekonomis bagi peternak unggas petelur skala breeder maupun komersil. Metode yang dikembangkan untuk deteksi EDS semakin efektif dan efisien melalui uji HA/HI, ELISA, PCR maupun Real time PCR. Sejauh ini langkah yang terbaik sebagai pertahanan dari infeksi EDS adalah penerapan biosekuriti, implementasi HACCP pada setiap tahapan produksi, kontrol nutrisi sesuai dengan kebutuhan, pemberian vitamin, suplementasi fitobiotik guna meningkatkan imun unggas petelur.

\section{DAFTAR PUSTAKA}

Absalón, A. E., A. Morales Garzon, P. F. Vera Hernandez, D. V. Cortes Espinosa, S. M. Uribe Ochoa, L. J. Garcia, dan E. Lucio Decanini. 2017. Complete genome sequence of a non pathogenic strain of Fowl Adenovirus serotype 11: Minimal genomic differences between pathogenic and non pathogenic viruses. Virology. 501:63-69.

Afandi, A., C. Christoporus, dan S. Hajar. 2019. Analisis kelayakan finansial usaha ayam petelur pada peternakan anas di kelurahan Pengawu kecamatan Tatanga kota Palu. Agrotekbis. 7(6): 694 - 703.

Amijaya, D. T., A. Yani, dan R. Rukmiasih. 2018. Performa ayam ras petelur pada letak cage berbeda dalam sistem closed house di global buwana farm. Jurnal Ilmu Produksi dan Teknologi Hasil Peternakan 6 (3): 98103.

Ashraf, A dan M. S. Shah. 2014. Newcastle Disease: Present status and future challenges for developing countries. African Journal of Microbiology Research. 8(5): 411-416.

Begum J.A., E. H, Chowdhury, R. Parvin, Md. A. Matin, M. Giasuddin, A.S.M Bari, Md. R. Islam. 2013. Detection of egg drop syndrome virus by polymerase chain reaction. International Journal of Livestock Research 3(2): 112-116.

Brown Jordan, A., Gongora, V. D Hartley, dan C Oura. 2018. A review of eight high-priority, economically important viral pathogens of poultry within the caribbean region. Veterinary Sciences 5 (1): 14 . DOI: https://doi.org/10.3390/vetsci5010014

Cha, S. Y., M. Kang, O. K. Moon, C. K. Park, dan H. K. Jang. 2013. Respiratory disease due to current egg drop syndrome virus in Pekin ducks. Veterinary microbiology. 165(3-4): 305-311.

DOI: https://doi.org/10.1016/j.vetmic.2013.04.0 04

Changjing, L., L. Haiying, W. Dongdong, W. Jingjing, W. Youming, W. Shouchun, L. Jida, L. Ping, W. Jianlin, X. Shouzhen, C. Shangjin, Z. Yi, dan Y. Yanbo. 2016. Characterization of fowl adenoviruses isolated between 2007 and 2014 in China. Vet Microbiol. 197:62-67. DOI: https://doi.org/10.1016/j.vetmic.2016.11.0 05

Dharmayanti, N.L.P.I., R. Hartawan, D. A. Dewajuli , R. Indriani . 2014. Phylogenetic analysis of genotype VII of new castle disease virus in Indonesia. African Journal of Microbiology Research 8(13): 13681374

DOI: https://doi.org/10.5897/ajmr2014.6601 
Ditjennak. 2014. Manual Penyakit Unggas. 2014. Direktorat Kesehatan Hewan Direktorat Jenderal Peternakan dan Kesehatan Hewan. Kementerian Pertanian. Hal 36.

Ezema, W. S., J. A. Nwanta, L. O. Aka,and E. V. Ezenduka. 2010. Egg-Drop Syndrome 76 in different bird species in Nigeria - A review of the epidemiology, economic losses, challenges and prospect for management and control. World's Poultry Science Journal. 66 (1): 115-121. DOI: https://doi.org/10.1017/S00439339100001 15

Fitzgerald, S. D., S. Rautenschlein, H. M. Mahsoub, F. W. Pierson, W. M. Reed, and S. W. Jack. 2019. Adenovirus infections. Diseases of Poultry. 321-363.

Gblossi, B. Goualie, S. Bakayoko, and K. J. Coulibaly. 2020. Practices of biosecurity measures and their consequences on poultry farms in abidjan district. Journal of Faculty of Food Engineering. 11 (1).

Gowthaman, V., S. D. Singh, K. Dhama, M. A. Ramakrishnan, Y. P. S. Malik, T. G. Murthy, R. Chitr, and M Munir. 2019. Coinfection of Newcastle disease virus genotype XIII with low pathogenic avian influenza exacerbates clinical outcome of Newcastle disease in vaccinated layer poultry flocks. Virus Disease. 30(3): 441452. DOI: https://doi.org/10.1007/s13337019-00533-6

Grimes, T., dan C. Jackson. 2015. Code of Practice for Biosecurity in the egg industry. Australian Egg Corporation: Sydney, NSW, Australia.

Hafez, H. M. 2011. Pakistan veterinary journal avian adenoviruses infections with special attention to inclusion body hepatitis/ hydropericardium syndrome and egg drop syndrome. Pakistan Veterinary Journal. 31(1): 85-92.

Haniarti, Munir, M. A. Akib. 2019. Kualitas jamu ternak pada berbagai bentuk sediaan dan kemasan. Prosiding Seminar Nasional 2018 Seminar Nasional Sinergitas Multidisiplin Ilmu Pengetahuan dan Teknologi (SMIPT). March. Vol 1.

Henry, B. K., R. J. Eckard, and K. A. Beauchemin. 2018. Review: Adaptation of ruminant livestock production systems to climate changes. Animal 12 (2): S445S456. $\quad$ DOI: https://doi.org/10.1017/S17517311180013 01

Ilyas, M. A., I. Hussain, M. Siddique, M. H. Rasool, M. K. Mansoor, andS. Manzoor. 2004. Evaluation of egg drop syndrome virus vaccines by measuring antibody levels in egg yolk in layers. International journal of agriculture and biology 6 (6): 981-983.

Kencana, G. A., I. N. Suartha, D. R. B. Nainggolan, dan A.S.L Tobing. 2017. Respons imun ayam petelur pascavaksinasi newcastle disease dan Egg Drop Syndrome. Jurnal Sain Veteriner 35(1): 81. DOI: https://doi.org/10.22146/jsv.29295

Kencana, G. A. Y., N. Suartha, I. M. Kardena, I. M., G. A. M. K., Dewi, and A. Nurhandayani. 2018. Potential and safety tests of egg drop syndrome candidate vaccine from medan isolate, Indonesia. Veterinary World 11(11): 1637. DOI: https://doi.org/10.14202/vetworld.2018.16 37-1640.

Kencana, G. A. Y., I. M. Kardena, dan P. M. Puspitayani. 2019. Seroprevalensi virus egg drop syndrome pada bebek petelur di kecamatan Negara, Kabupaten Jembrana, Provinsi Bali. Jurnal Veteriner 20 (2): 248254.

Krauze, M., M. Cendrowska-Pinkosz, P. Matusevicius, A. Stępniowska, P. Jurczak, and K. Ognik. 2021. The effect of administration of a phytobiotic containing cinnamon oil and citric acid on the metabolism, immunity, and growth performance of broiler chickens. Animals. 11(2): $\quad 399 . \quad$ DOI: https://doi.org/10.3390/ani1 1020399

Liu, R., H. Ma, J. Shu, Q. Zhang, M. Han, Z. Liu, and $X$. Wu. 2020. Vaccines and therapeutics against Hantaviruses. Frontiers in Microbiology. 10: 2989. DOI: https://doi.org/10.3389/fmicb.2019.02989

Liu, X. D., A. Jang, B. D. Lee, S. K. Lee, M. Lee, and C. Jo. 2009. Effect of dietary inclusion of medicinal herb extract mixiin a poultry ration on the physico-chemical quality and oxidative stability of eggs. AsianAustralasian Journal of Animal Sciences. 
22(3):

421-427.

https://doi.org/10.5713/ajas.2009.80334

Mansoor, M. K., I. Hussain, M. Arshad, and G. Muhammad. 2011. Preparation and evaluation of chicken embryo - adapted fowl adenovirus serotype 4 vaccine in broiler chickens. Tropical Animal Health Production. 43:331-338. DOI: https://doi.org/10.1007/s1 1250-010-9694-z

Marek, A., G.vL. Kajan, C. Kosiol, B. Harrach, C. Schlotterer, and M. Hess. 2014. Complete genome sequences of pigeon adenovirus 1 and duck adenovirus 2 extend the number of species within the genus aviadenovirus. Virology. 462-463:107-114.

McFerran, J. B., R. M. Rowley, M. S. McNulty, dan L. J. Montgomery. 1977. Serological studies on flocks showing depressed egg production. Avian Pathology 6 (4): 405413.

Meirhaeghe, H. van, A. Schwarz, J. Dewulf, F. van Immerseel, B. Vanbeselaere, dan $<$. de. Gussem. 2019. Transmission of poultry diseases and biosecurity in poultry production. Biosecurity in animal production and veterinary medicine: from principles to practice. CABI. pp. 329-356).

Ockiya, T.A. Jarikre, A.T. Jibril, and C. A. O. Adeyefa. 2020. Detection and partial nucleotide sequence of egg drop syndrome virus from a poultry flock in Ogun State, Nigeria. Archive of Science \& Technology. 1: 98-109.

Okolelova, T. M., Engashev, S. V., and Salgereev, S. M. 2017. Nutritional factors influencing health condition of the egg-laying organs. Ptitsevodstvo (8): 37-41.

Ooi, P. S., A. R. Rohaida, A. D. Nur Hardy, D. Devina, A. H. Borhan, S. Kartini, M. A. Rahman, and A. R. Alimon. 2018. Effect of local medicinal herbs as feed additives on production performance and faecal parameters in laying hens. Malaysian Journal of Animal Science 21(2): 59-67.

Park, J. A., dan S. H. Sohn. 2018. The influence of hen aging on eggshell ultrastructure and shell mineral components. Korean Journal for Food Science of Animal Resources 38(5): $\quad 1080-1091 . \quad$ DOI: https://doi.org/10.5851/kosfa.2018.e41
Peña-Rueda, Y., Peña-Rueda, Y. F., Benítez, D., Ray, J. V., \& Fernández-Romay, Y. 2018. Determinant factors of livestock production in a rural community in the southwest of Holguín, Cuba. Cuban Journal of Agricultural Science, 52(2).

Poudel, U., U. Dahal, N. Upadhyaya, S. Chaudhari, and S. Dhakal. 2020. Livestock and poultry production in Nepal and current status of vaccine development. Vaccines. 8 (2): $1-9$. DOI: https://doi.org/10.3390/vaccines8020322

Raj, G. D., Sivakumar, S., Matheswaran, K., Chandrasekhar, M., Thiagarajan, V., \& Nachimuthu, K. 2003. Detection of egg drop syndrome virus antigen or genome by enzyme-linked immunosorbent assay orpolymerase chain reaction. Avian Pathology. 32 (5): 545-50. DOI: https://doi.org/10.1080/03079450310001596719

Saeed, S., B. J. Jalal, A.S. Shaker, S. Mohammed, S. Kirkuki, dan S. Rawf Aziz. 2017. Influence of genotype and hen age on the egg shape index. International Journal of Biochemistry. 2(6): 68-70.

Samanta, I., S. N. Joardar, and P. K. Das. 2018. Biosecurity strategies for backyard poultry: a controlled way for safe food production. Food Control and Biosecurity. 16: 481-517.

Setiawati, T., R. Afnan, dan N. Ulupi. 2016. Performa produksi dan kualitas telur ayam petelur pada sistem litter dan cage dengan suhu kandang berbeda. Jurnal Ilmu Produksi dan Teknologi Hasil Peternakan 4(1): 197-203

Song, Y., Q. Wei, Y. Liu, Y., Bai, R. Deng, G. Xing, and G. Zhang. 2019. Development of novel subunit vaccine based on truncated fiber protein of egg drop syndrome virus and its immunogenicity in chickens. Virus Research 272: 197728.

Suartha, I.N., I. M. S. Antara, I. K. S Wiryana, I. M. Sukada, I. W. Wirata, N. M. R. K. Dewi, dan I. G. N. K. Mahardika. 2010. Peranan pedagang unggas dalam penyebaran virus Avian Influenza. Jurnal Veteriner. 11(4): 220-225 
Suresh, P., K. Shoba, dan R. J. Johnson. 2013. Incidence of egg drop syndrome - 1976 in Namakkal district, Tamil Nadu, India. Veterinary World 6 (6): 350-353.

Trijaya, G. P. 2017. Penerapan biosekuriti pada peternakan ayam broiler milik Orang Asli Papuaa (OAP) di Kabupaten Nabire. Jurnal Fapertanak 2 (1): 61-73.

Vinus, R. Dalal, N. Sheoran, N.S. Maan dan B.S. Tewatia. 2018. Potential benefits of herbal supplements in poultry feed: A Review. The Pharma Innovation Journal 2018; 7(6): 651656.

Vogel, O. A., and B. Manicassam. 2020. Broadly protective strategies against influenza viruses: universal vaccines and therapeutics. Frontiers in Microbiology 11: 135.

DOI: https://doi.org/10.3389/fmicb.2020.00135

Widodo, E. 2020. The Prospective use of essential oil from herbs as feed additive for laying poultry: A Review. In IOP Conference Series: Earth and Environmental Science. 478(1): 012003. IOP Publishing. DOI: https://doi.org/10.1088/17551315/478/1/012003
Widodo, N., dan H. Khasanah. 2021. The effect of binahong leaf meal (Anredera cordifolia (ten.) Steenis) as feed additive on digestive organs profile of broiler chickens. IOP Conference Series: Earth and Environmental Science, 759(1), 012024.

Yulianti, D. L., P. Trisunuwati, O. Sjofjan, dan E. Widodo. 2015. Effect of andrographis paniculata a phytobiotic on consumption, feed conversion and Mojosari duck egg Production. International Journal of Poultry Science 14(9): 529.

Zeng, T., Z. Xie, L. Xie, X. Deng, Z. Xie, S. Luo, and J. Huang. 2015. Development of duplex real-time fluorescence RT-PCR assay for differential detection of Tembusu virus and egg drop syndrome virus. China Poultry 37(1): 17-21.

Zheney, M., Z. Kaziyev, G. Kassenova, L. Zhao, W. Liu, L. Liang, dan G. Li. 2018. Realtime fluorescence loop-mediated isothermal amplification assay for direct detection of egg drop syndrome virus. BMC Veterinary Research 14(1): 1-8. 